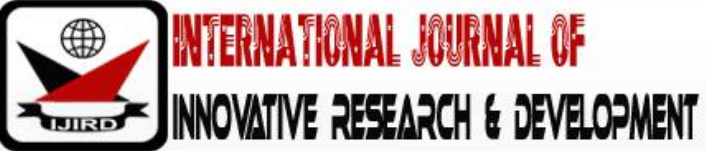

ISSN 2278 - 0211 (Online)

\section{The Impact of Taxation on Economic and Infrastructural Development in Nigeria}

\author{
Emmanuel Gbadebo Adeniran \\ Principal Lecturer, Department of Banking and Finance, Oke Ogun Polytechnic, Nigeria
}

\begin{abstract}
:
From the perspective of Nigerian Government, tax is a major source of earning revenue. It plays significant role behind the development of Nigerian economy. The primary objective of this study is to check how taxation affecting the Nigerian economic and infrastructural development. From 2000 to 2017, data has been collected and used for the analysis purpose. Expo facto research design has been adopted here. There variables i.e. petroleum profit tax, company income tax, and value added tax have been highlighted here. Reference has been drawn from Federal Inland Revenue Service, Central Bank of Nigerian and World Fact books. Finding showed that these three variables are showing positive and significant relationship. This study also suggested some of the recommendation for the future.
\end{abstract}

Keywords: Gross domestic product, Infrastructural development, taxation

\section{Introduction}

For every government, it is a primary responsibility to ensure welfare, security and freedom of its citizen. For this the government must need proper and sufficient funding. Unfortunately, government has to face many obstacles due to increasing population of citizens and technological advancement. In Nigeria main resources of government come from taxes and revenue. Tax is popular and most common tools for generating the needed finance by a government (Oti and Odey, 2016). Taxation can be considered as a compulsory transfer or payment (Anyawu, 1997).

Almost every society depends on taxation (Azubike, 2009). Most of government collect additional revenue from taxation. It is an efficient means of yoking a nation's internal resources.

Now-a-days, in Nigeria, huge changes have been done in the taxation sector. The laws and regulations have been reviewed. In the area of Nigerian law tax revenue, three tiers of government are present Federal, State and Local Governments.

The main reason for collecting tax is to develop economy, infrastructure, welfare of common people. It enables the provision of basic amenities for improved public services through proper administrative system and structures (Garba, 2014). If loopholes hound in tax structure, it can be easily understood that growth will suffer severely.

In Nigeria, just like other nations (Netherland, Canada, United States of America and United Kingdom) macroeconomic stability gets influenced by world tax rate. Some of the common sources of revenues are Company Income Tax (CIT), Value Added Tax (VAT), Import Duties and have used same to create prosperity (Adegbie, 2010).

As per Festus \& Samuel (2007), the Nigerian government had expressed severe disappointment in the sector of non - oil tax revenue. Social and economic infrastructures can be severely improved via proper taxation structure (Adereti, Sanni\& Adesina, 2011).

In Nigeria, due to problem in tax-collection structure, infrastructure and social amenities are lagging behind. Despite of rich in oil-resources, due to poor electoral processes, power supply, restrictive trade policies, restrictive trade policies it is suffering up to great extent (Central Bank of Nigeria Statistical Bulletin, 2014).

Too much dependence on the oil revenue has caused problems in political, economic and social development. A continuous decline in the price of crude oil has been observed below the budget benchmark. A miscommunication has been observed in the tax collecting structure. Several disparities have been observed in the relationship between tax revenue, economic and infrastructure development in Nigeria.

\section{Literature Review}

\subsection{Conceptual Approach of Taxation}

Taxation is an important instrument used by government to raise fund from its citizens (Anyawu, 2004). It is a rule imposed on citizens to pay certain portion to government from their income, profit or wealth. Both individuals as well as organizations has to pay tax. The primary objective of collecting tax is to improve the economy and to provide better welfare and improved security to its citizens. Through proper redistribution of wealth collected through taxation helps in smooth wealth management of an economy (Jhingan 2004; Bhartia, 2009; Ogbonna \&Ebimobowei, 2012). Tax is a 
contribution from persons for the support of the government and all private needs (Appah \& Oyandonghan, 2011; Appah, 2004). Jhingan (2002) and Anyanwu (1993)). The purpose is to reduce economic inequalities. According to Ogbonna and Ebimobowei (2012) taxation helps to achieve stabilization in economy. Piana (2003) highlighted the application of tax rate to a tax base. Proper prioritization in expenses can be made by governments if a properly maintained tax system is present (Brautigam, 2008). Democratic accountability can be achieved through properly maintained tax system.

Public sectors can finance its activity through taxation that helps to achieve nation's economic and social goals. Moreover, social justice (Ola, 2001) can be ensured through redistribution of wealth, in which taxation helps. Fiscal policy instruments in both micro and macro economy can be developed through taxation (Olawumi \& Ayinla, 2007). Buba (2007), highlighted about Petroleum Profit and Tax (PPT) Act 1990. As per this act, oil companies operate under production are liable to pay tax at a rate of $50 \%$ (Garba, 2014). In Nigeria, petroleum sector is contributing highest in the generation of GDP (Onaolapo, Fashina \& Adegbite, 2013). As per the rule of Companies Income Tax (CIT), all registered corporate entities other than those engaged in petroleum operations should pay tax 30\% of the profit (Dike, 2014, Adereti, 2011). For a company which operates in multiple countries corporate taxation becomes complex (Zucman, 2014). Companies' income tax is not the largest contributor in Nigerian economy. Value Added Tax (VAT) is born by the final consumer of the product or service (Onwucheke \& Aruwa, 2014). VAT is a consumption tax embraced by many countries worldwide (Federal Inland Revenue Service, 1993). It regulates the collection of tax due on vatable goods or services (Adereti, 2011). It requires a taxable person upon registering the Federal Board of Inland Revenue to charge and collect VAT at flat rate of $5 \%$ of all invoiced amounts of taxable goods and services (Ariyo, 1998). It contributes to the labors' raw materials of purchases before selling the processed goods or services (Okolie \& Afolayan, 2015).

\subsection{Infrastructures Development in Nigeria}

Infrastructure is must for development. Waziri, Ali and Nuru (2014) mentioned that the physical structures necessary for the functioning of society. Oisasoje and Ojeifo (2012) describe infrastructure as developmental driver. Infrastructural development helps to achievegrowth rate of income per capital.

Todaro and Smith (2011) highlighted that infrastructural development can be facilitated and accelerated by the presence of physical, social and economic infrastructure (Migap, 2014).

Infrastructure is very important for coping with population growth, reducing poverty, improving welfare of citizens (Mobolaji \& Wale, 2012).

\subsection{Theoretical Review}

For this study, the optimal theory of taxation has been adopted. There are three major contributors i.e. Ramsey (1927) who advocates linear commodity taxation to raise revenues and redistribute; Pigou (1920) who advocates the linear commodity taxation to correct for externality; and Mirrlees (1971) who advocates the nonlinear income taxation. Optimal taxation acts as a social planner for achieving social welfare. It acts on the utilities of individuals in the society. As per this theory the government is the social planner. The government is responsible for providing the various infrastructural facilities with the use of revenue received from tax. Thus, this is the motivation for this study.

\subsection{Empirical Studies}

Many studies have focused on economic and infrastructural development to tax revenue. An analytical study conducted by Ajakaiye (1999) explored the impact of Value Added Tax (VAT) on growth of Nigerian economy. Adereti, Adesina and Sanni (2011) also focused on the Gross Domestic Product (GDP) on Value Added Tax (VAT), responsible for the economic growth by the variation of VAT revenue earnings in Nigeria. Ofoegbu, Akwu \& Oliver (2016) analyzed the effect of tax revenue on economic development of Nigeria with time series data for the period of 2005-2014. Positive and significant relationships have been found between tax revenue and economic development.

On the other hand, study conducted by Akinwale (2010) highlighted the problem in infrastructure in Nigeria. This study highlighted about improper fund raised due to negligence and corruption. Anyaduba (2015) and Arowan (2015)inspected the impact of tax revenue by using a dataset collected for the period of 1980-2014. This study revealed that Company Income Tax (CIT) and Education Tax (ET) have noteworthy impression on infrastructural development. Zhattua (2013) powerfully preached that taxation has two board determination in developing nations.

\section{Methodology}

This study adopted Ex post facto research design. The reason for the use is that required data are not manipulated. Total revenue collected by the federal government was regressed on tax revenue (petroleum profit tax, company income tax, value added tax) which were used as proxy for tax reform (as cited in Garba, 2014). Time series variables obtained from public journals of Federal Inland Revenue and Service (FIRS) and Central Bank of Nigeria (CBN). Statistical bulletins and World fact books of various years were employed. The scope of the work spanned from 2000-2017. In order to lend empiricism to the study, regression technique was used. The regression technique is suitable as well used in similar studies Ajakaiye (1999), Okafor (2012), Garba (2014), Adereti, Adesina \& Sanni (2011) due to its unique properties of linearity, sufficiency, least variances unbiasedness and lease mean errors. The data were analyzed with Vector Error Collection Model (VECM) using the E-views 6.0 statistical package. The order of integration was examined using Augmented Ducky Fuller (ADF) tests. 


\subsection{Model Specification}

In this study, the following relating equations are developed to propose prior to expectation on the dependent and independent variables. The model used in this study is an adaptation of the model by Anyaduba \& Aronwan (2015), who examined the impact of tax revenue on infrastructural development in Nigeria; and model by Garba (2014), who examined the impact of taxation on economic development in Nigeria. The models they used are:

$\mathrm{GDP}=\mathrm{f}(\mathrm{PPT}, \mathrm{CIT}, \mathrm{VAT}, \mathrm{ET}, \mathrm{PIT}, \mathrm{CED})$...eq(1)

IFRAC $=\mathrm{f}(\mathrm{CIT}, \mathrm{PPT}, \mathrm{VAT}, \mathrm{ET}$,$) ....eq(2)$

Where, PPT = Petroleum Profit Tax; CIT= Companies Income Tax; VAT= Value Added Tax; ET= Education Tax; PIT= Personal Income Tax; $\mathrm{CED}=$ Custom and Excise Duties; GDP = Gross Domestic Product; IFRAC= Infrastructure Development.

Therefore, the model used in this current study is given as equation 3 and 4, these are analyzed using the Ordinary List Square regression technique and Error Correction Model.

$\mathrm{GDP}=\mathrm{f}(\mathrm{PPT}, \mathrm{CIT}, \mathrm{VAT})$

IFRAC $=\mathrm{f}(\mathrm{PPT}, \mathrm{CIT}, \mathrm{VAT})$

Where:

GDP= Gross Domestic Product

IFRAC= Infrastructural Development (Captured using percentage of electricity produced from hydroelectric source) PPT=Petroleum Profit Tax

CIT=Company Income Tax

VAT=Value Added Tax

$\beta 0=$ constant

$\beta 1-\beta 3=$ PARAMETER to be estimated

$\mu_{\mathrm{t}}=$ error term

the explicit forms of the functional relationship of the variables expressed above are presented in equations $5 \& 6$ :

$\mathrm{GDP}=\beta_{0}+\beta_{1} \mathrm{PPT}+\beta_{2} \mathrm{CIT}+\beta_{3} \mathrm{VAT}+\mu_{\mathrm{t}}$

IFRAC $=\beta_{0}+\beta_{1}$ PPT $+\beta_{2}$ CIT $+\beta_{3}$ VAT $+\mu$

\section{Results and Findings}

\begin{tabular}{|c|c|c|c|}
\hline Variables & ADF-Statistics & $\mathbf{9 5 \%}$ ADF & $\begin{array}{c}\text { Critical Values Order of } \\
\text { Integration }\end{array}$ \\
\hline GDP & -6.51914 & -3.57785 & $\mathrm{I}(1)$ \\
\hline IFRAC & -3.46302 & -2.6531 & $\mathrm{I}(1)$ \\
\hline PPT & -4.54724 & -2.32423 & $\mathrm{I}(1)$ \\
\hline CIT & 0.000 & & $\mathrm{I}(1)$ \\
\hline VAT & -5.21348 & -2.68154 & $\mathrm{I}(1)$ \\
\hline
\end{tabular}

Table 1: Augmented Ducky Fuller Unit Root Test

Source: Author's fieldwork (2015)

In the Table 1 above, the tool of ADF is tested for all variables such as GDP, IFRAC, PPT, CIT and VAT. It is obvious from the result that the ADF test statistic value is less than the critical value at $1 \%$ level of significance. Therefore, it shows that GDP, IFRAC, PPT, CIT and VAT are stationary and integrated of same order that is I(1).

\begin{tabular}{|c|c|c|c|c|}
\hline Variables & Coefficient & Std.Error & T-Statistics & P.Value \\
\hline Constant & 36.3125 & 0.65451 & 37.1801 & 0.0001 \\
\hline PPT & 0.35433 & 4.17686 & 0.53413 & 0.000 \\
\hline CIT & 0.3955 & 10.5853 & 1.28022 & 0.003 \\
\hline VAT & 0.13047 & 0.27584 & 0.58605 & 0.001 \\
\hline \multicolumn{5}{|c|}{ R2=0.83165 } \\
Adj. R2=0.640254 \\
Std.Err $=4.263513$ \\
F-Stat. $=3.547010$ \\
Prob.(F-Stat) $=0.000$
\end{tabular}

Table 2: Vector Error Correction Result of Taxation and GDP

Dependent variable: GDP

Estimate Model:5

$G D P=36.3125+2.313 P P T+16.395 C I T+0.13047 V A T+\mu_{t}$ 
During the long run period 2000 to 2017, the T-Statistic Value for petroleum profit tax was 0.53413, with standard error of 4.17686 and the coefficient is 2.313 at 0.000 significant level. This implies that for $1 \%$ increase in petroleum profit tax, GDP will increase by $35.4 \%$. this indicates that petroleum profit tax has positive and significant relationship with economy in Nigeria. This study is in agreement with the study of Garba (2014).

The company income tax within a long run period of 2000 to 2017 shows a positive and significant relationship with GDP, as the T-Statistic is 1.28022 with a standard error of 10.5853 and coefficient is 0.3955 to 0.003 significant value. This signifies that for 1\% increase in company income tax, GDP will increase by $39.6 \%$. This exemplifies that taxes realized from companies in Nigeria contributed positively to the economic growth of Nigeria. This may be as a result of the effectiveness of both the State Internal Revenue Board and Federal Inland Revenue Services. This study is corroborated with the study of Festus and Samuel (2007) who in their study found that company income tax has a positive relationship on Nigeria economic growth.

The Value Added Tax within a long run period of 2000 to 2017 reviews that T-Statistic value of 0.58605 with standard error of 0.27584 and coefficient is 0.13047 at 0.001 significant level. This implies that $1 \%$ increase in value added tax generated by government, GDP will increase by $13.1 \%$. this is supported with the study of Adereti, Adesina and Sanni (2011). Furthermore, the overall significance of the entire model as measured by the F-stat. which is 3.547010 is statistically significant at 0.01 . This result signifies that PPT, CIT and VAT are good predictors of economic growth in Nigeria.

\begin{tabular}{|c|c|c|c|c|}
\hline Variables & Coefficient & Std.Error & T-Statistics & P.Value \\
\hline Constant & 15.3435 & 0.31421 & 18.15013 & 0.000 \\
\hline PPT & 0.3133 & 4.07486 & 0.5672 & 0.0001 \\
\hline CIT & 0,3420 & 11.7893 & 1.39071 & 0.002 \\
\hline VAT & 0,24513 & 0.37487 & 0.34804 & 0.000 \\
\hline \multicolumn{5}{|c|}{ R2= 0.72895 } \\
Adj. R2 $=0.530153$ \\
Std.Err $=4.357323$ \\
F-Stat. $=3.667020$ \\
Prob. (F-Stat.) = 0.000
\end{tabular}

Table 3: Vector Error Correction Results of Taxation and Infrastructural Development

Dependent variable: IFRAC

Estimate Model 6:

$I F R A C=15.3435+0.3133 P P T+0.3955 C I T+0.13047 V A T+\mu_{t}$

During the long run period 2000 to 2017, the T-statistic value for petroleum profit tax is 0.5672 with standard error of 4.07486 and the coefficient is 0.3133 at 0.001 significant level. This implies that for $1 \%$ increase in petroleum profit tax infrastructural development will increase by $31.3 \%$. this indicates that petroleum profit tax has positive and significant relationship with infrastructural development in Nigeria. This study is in agreement with the study of Anyaduba and Aronwan (2015). The company income tax within a long run period of 2000 to 2017 shows a positive and significant relationship with infrastructural development as the T-statistic is 1.39071 with a standard error of 11.7893 and coefficient is 0.3320 at 0,0020 significant value. This signifies that for $1 \%$ increase in company income tax, infrastructural development will increase by $34.2 \%$. This exemplifies that taxes realized from companies in Nigeria contributed positively to the infrastructural development in Nigeria. This study is corroborated with the study of Anyaduba and Aronwan (2016). The Value Added Tax within a long run period of 2000 to 2017 reveals that T-statistic value of 3.4804 with standard error of 0.37487 and coefficient is 0.24513 at 0.001 significant level. This implies that $1 \%$ increase in value added tax generated by government, infrastructural development will increase by $24.5 \%$ this is supported with the study of Anyaduba and Aronwan (2015). In addition, the overall significance of the entire model as measured by the F-statistic demonstrates that the F-stat. which is 3.667020 is statistically significant as 0.01 .

\section{Conclusion and Recommendation}

This paper has successfully suggested some steps to improve the tax revenue, economic and infrastructural development in Nigeria. GDP and infrastructural development have done to economic and infrastructural development in Nigeria. Needless to say, all the suggestions are important and relevant for infrastructural and economic development in Nigeria. Almost all the variables covered under this study showed significant and positive relationship with economic and infrastructural development in Nigeria. Hence, a strict lesson can be learned that no area in tax collection should be untouched. Electronic mode has been suggested to collect the tax. The intent of government should be communicated to the general public. Set up of a separate governing body has been suggested.

\section{References}

i. Adegbie, F.F. (2010). Customs and exercise duties contribution towards the development and growth of Nigerian economy. European journal of economics, finance administrative sciences, 29.

ii. Adegbite, T.A. (2015). The analysis of the effect of corporate income tax (cit) on the revenue profile in Nigeria. American journal of Economics, Finance and Management, 1(4): 312-319

iii. Adereti, S.A. Sanni M. R. \& Adesina J. A. (2011). Value added tax and economic growth of Nigeria. Journal of Humanities and social science. 10 (1): 456-471 
iv. Ajakaiye, D.O. (1999). Macroeconomic effect of VAT in Nigeria: A computable general equilibrium analysis ', AERC Research paper 92

v. Ajakaiye, O.D. (2000). Macroeconomic effect of VAT in Nigeria. A computable, general equilibrium analysis African Economic Research Consortium Retrieved from unpanl.un.org.

vi. Akinwale, A.A. (2010). Menace of inadequate infrastructures in Nigeria. African Journal of Science, Technology, Innovation and Development, 2(3): 207-228

vii. Anyaduba, J.O. \&Aronwan, E.J. (2015). Taxes and Infrastructural development in Nigeria. Nigerian Journal of Banking, Finance and Entrepreneurship Management 1: 14-28

viii. Anyanwu, J.C. (1997). Nigerian Public Finance. Joanne Educational Publishers, Onitsha.

ix. Anyanwu, J.C. (2004). Monetary Economics: Theory, policy and institutions. Onitsha: Hybrid Publishers.

x. Appah, E. \& Oyandonghan, J.K. (2011). The challenges of tax mobilization are management in the Nigerian Economy. Journal Business Administration Manage, 6(2): 128-136.

xi. Appah, E. (2010). The problems of tax planning and administration in Nigeria: the federal and state governments experience. Int. J. Lab. Organ., Psychol., 4(1-2): 1-14.

xii. Arijo, A. (1998). Productivity of the Nigerian tax system: 1970 to 1990. African Economic Research Consortium, Nairobi Kenya.

xiii. Azubuike, J.U.B (2009). Challenges of tax authorities, taxpayers in the management of tax consultants' option revisited. European Journal of Social Sciences, 8(4): 532-539.

xiv. Bhartia, H.L. (2009). Public finance (14thEdn). New Delhi: Vikas Publishing House PVT Ltd.

xv. Brautigam, D., (2008). Taxation and governance in Africa, AEI online. Retrieved from http://www.aei.org/publication/taxation-and-governance-in-africa

xvi. Central Bank of Nigeria (2014). Statistical Bulletin Published 7/8

xvii. Commonwealth Business Council (CBC), (2013). The African investment Business Report 2013. London: UK. Author

xviii. Federal Inland Revenue Service Handbook, 2012

xix. Federal Inland Revenue Services (1993). Information Circular No. 93.

xx. Festus A. F. and Samuel F.A. (2007). Company income tax and Nigeria economic development., European Journal of Social Sciences, 22(2).

xxi. Garba, L.S. (2014). Tax revenue and economic growth in Nigeria. Unpublished M.Sc. Zaria.

xxii. Jhingan, M.L. (2002). The Economics of Development and Planning. New Delhi: Vrinda Publications CP. Ltd.

xxiii. Jhingan, M.L. (2004). Money, Banking, International Trade and Public Finance New Delhi, India; Vrinda Publications,

xxiv. Ofoegbu, G.N, Akwu, D.O \& Oliver, O. (2016). Empirical analysis of effect of tax revenue on economic development of Nigeria. International Journal of Asian Social Science. 6(10): 604-613

xxv. Ogbonna, G.N. and Ebimobowei A. (2011). Impacts of Petroleum revenue and the economy of Nigeria Current Research Journal of Economic Theory, 4(2): Maxwell Scientific Organization.

xxvi. Ogbonna, G.N. and Ebinbowei A. (2011). Impact of tax reforms and economic growth in Nigeria. Maxwell Scientific Organization.

xxvii. Oisasoje, O. M. \& Ojeifo, S.A. (2012). The role of public infrastructure in poverty reduction in the rural areas of Edo State, Nigeria. Research on Humanity and Social Sciences, 2(7).

xxviii. Okafor, R.G. (2012). Tax revenue generation and Nigerian Economic Growth. Journal of Business and Management, 4(19), 49-56.

xxix. Okolie, M.N., \& Afolayan S.M. (2015). Correlation between Value Added Tax (VAT) and National Revenue in Nigeria: and ECM Model. Research Journal of Finance and Accounting, 6(6) 230-238.

xxx. Ola, C.S. (2001). Income Tax Law and Practice in Nigeria. Ibadan: Heinenmann Educational Books (Nig) Plc,

xxxi. Onaolapo A.A, Fasina H.T \& Adegbite T.A, (2013). The analysis of the effect of petroleum profit tax on Nigerian Economy, Asian Journal of Humanities and Social Sciences 1(1), 25-36.

xxxii. Onwuchekwa, J. C, \& Aruwa, S.A.S, (2014) Value Added Tax and economic growth in Nigeria. European Journal of Accounting Auditing and Finance Research, 2(8), 62-69

xxxiii. Oti P.A \& Odey, F.I. (2016). Tax reforms and revenue trend in Nigeria. The dyadic interact Research Journal of Finance and Accounting, 7(19): 84-92

xxxiv. Waziri S, Ali, G. B., \& Nura M., (2014). Sustainable infrastructure development in Nigeria: Challenges of the Challenges of the sector. International Journal of Development and Sustainability, 3(7): 1488-1495.

xxxv. Zhattua, V.S. (2013). Fiscal policy as an engine of economic growth in Nigeria. An International Journal of Arts and Humanities, 2(2): 282-298.

xxxvi. Zucman, G., (2014). Taxing across borders: tracking personal wealth and corporate profits. Journal of Economic Perspectives, 28(4): 121-148. 